\title{
TO STUDY EFFICACY OF JIVANTYADI GHRIT AS ADD-ON TREATMENT IN PTB TREATING WITH AKT (DOTS) REGIMEN
}

\author{
Dr. Nandkishor Bhaurao Kale ${ }^{1 \square}$
}

${ }^{1}$ Assistant Professor, Department of Rognidan and Vikrity Vigyan Shri Gurudeo Ayurveda College, Guru Kunj Ashram, Amravati Maharashtra, India
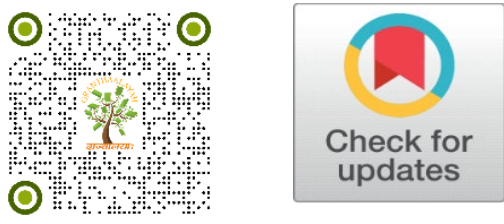

Received 10 November 2021

Accepted 01 December 2021

Published 18 January 2022

\section{CorrespondingAuthor}

Dr. Nandkishor Bhaurao Kale, nandkishorkale412@gmail.com

DOI 10.29121/jahim.v2.i1.2022.17

Funding: This research received no specific grant from any funding agency in the public, commercial, or not-for-profit sectors.

Copyright: (C) 2022 The Author(s). This work is licensed under a Creative Commons Attribution 4.0 International License.

With the license CC-BY, authors retain the copyright, allowing anyone to download, reuse, re-print, modify, distribute, and/or copy their contribution. The work must be properly attributed to its author.

\section{ABSTRACT}

Background: Patients of Pulmonary Tuberculosis continued to be suffering from the adverse effects of the Anti-tubercular drugs even though they are used efficiently, the rate of infection of pulmonary tuberculosis is not satisfactory under control. Hence the present study was conducted, to study the efficacy and to minimize the side effects of present therapy (DOTs) by using along with Ayurveda formulation.

Objectives: To Study the efficacy of Jivantyadi Ghrit as Add-on treatment in PTB treating with AKT (DOTs) regimen.

Materials and Methods: It was an open labelled, controlled clinical study. It was conducted in 28 patients of PTB for six months.

Results: There was significant reduction in group B patients regarding cough with expectoration, loss of appetite, loss of weight, evening rise of temperature, burning feet and hands. Significant reduction in side effects. There was significant reduction of score in lymphocyte count in group B patients.

Conclusion: Study shows the scientific good evidence of add-on therapy of Jivantyadi Ghrit with AKT (DOTs) in the management of PTB.

Keywords: Pulmonary Tuberculosis, Jivantyadi Ghrit, DOTs

\section{INTRODUCTION}

Tuberculosis is caused by Mycobacterium tuberculosis, which is communicable, chronic granulomatous disease. Kasper et al. (2005) It usually involves the lungs, hence the pulmonary tuberculosis because of the high content of the lipase. The centres of tubercular granulomas undergo caseous necrosis. Kumar et al. (2007) It causes 2 million deaths per year all over the world. In India, 90\% cases of TB have pulmonary tuberculosis hence it remains the major health problem in most developing countries. Rajayakshma, a disease of Pranavaha strotas explained by our Acharya, called as Rog of Raja which explains the seriousness of the disease. Rasadi dhatu kshay and kriya shay (loss of function) are the main samprapti factors. 
Sharma (2007) Rajayakshma described as aupsargik roga i.e., communicable disease. Shastri et al. (2008) Acharya not mentioned about the Jivanu (Bacteria) but utpadak (causative) karana are important factors in the samprapti of the disease which is to be taken significantly for chikitsa and pathyapathya. Jwara (fever), Kasa (cough), Kaphanishthivan (expectoration), Hastapadtaldaha (Burning feet and hands), Kshudhamandya (Reduced appetite) are the classical symptoms of Rajayakshma mentioned in Ayurveda. Shastri (2005) Modern medical science also explains about the same symptomatology of tuberculosis. Rajayakshma could be compared to tuberculosis from modern perspective. Anti- tubercular drugs (DOTs) are used for the treatment Tripathi (2018). However, the rate of infection of PTB is not satisfactory under control with many side effects and adverse reactions of the present therapy. Hence it was decided to use Jivantyadi Ghrit in PTB treating with AKT (DOTs) as an add-on therapy. So that the side effects will be minimized, and the efficacy of the present therapy will improve.

\section{MATERIALS AND METHODS 2.1. MATERIALS}

Jivantyadi Ghrit was prepared and physiochemical tests like

Refractive index (1.4544 at 40 Deg c), moisture (0.05\% w/w at 40 Deg c), Acid value $(1.77 \mathrm{mgKOH} / \mathrm{g})$, Iodine value $(30.68 \mathrm{gI} / 100 \mathrm{gm})$, saponification value (230.23mgKOH/g) were done.

Table 1

\begin{tabular}{|c|c|c|c|c|}
\hline S. No. & Ingredients & Latine Name & Useful Part & Quantity \\
\hline 1 & Jivanti & Leptadenia Reticulata & Root & 1 pala \\
\hline 2 & Yashtimadhu & Glycyrrhiza glabra L. & Root & 1 pala \\
\hline 3 & Munukka & Vitis vinifera $L$ & Fruit & 1 pala \\
\hline 4 & Kutaj & Holarenna anti-dysentrica Wall & Seed & 1 pala \\
\hline 5 & Kachora & Hedychium spichatum Ham. ex. smith & Root & 1 pala \\
\hline 6 & Pushkarmool & Inula racemosa Hook.f. & Root & 1 pala \\
\hline 7 & Kantkari & Solanum xantho-carpum L. & Panchang & 1 pala \\
\hline 8 & Gokshur & Tribulus terrestris L & Fruit, Root & 1 pala \\
\hline 9 & Bala & Sida cordifolia L. & Root, Seed & 1 pala \\
\hline 10 & Nilkamal & Nelumbo nucifera G. & Panchang & 1 pala \\
\hline 11 & Bhuiawala & Phyllanthus niruri Hook.f. & Panchang & 1 pala \\
\hline 12 & Traymana & Gentiana kurro Royle & Root & 1 pala \\
\hline 13 & Dhamasa & Fagonia Arabica L & Panchang & 1 pala \\
\hline 14 & Pimpali & Piper longum L. & Fruit, Root & 1 pala \\
\hline 15 & Ghee (Ghrit) & ------ & -------- & 1 prastha \\
\hline 16 & Water & ---- & ----- & 10 prasthas \\
\hline
\end{tabular}

\subsection{METHODOLOGY}

Study Design: The study was randomized, controlled clinical trial. After obtaining permission from Institutional ethics committee study was initiated. Total 54 patients were randomly allocated for present study as per equal block randomization method. 


\subsection{PARTICIPANTS}

Inclusion Criteria: Participants was willing to provide informed consent and agrees for providing complete follow up for the study period was included in the study. Participants of either sex aged between 18-60 years; diagnosis of PTB as per RNTCP guidelines; presenting with the classical signs and symptoms of pulmonary tuberculosis viz. cough with expectoration, evening rise fever, loss of appetite, loss of weight, burning feet and hands etc.; no significant medical or surgical disease/s at the time of screening were included.

Exclusion Criteria: Participants below 18 and above 60 years of age; subjects seriously ill with pulmonary tuberculosis; subjects participating or participated in another clinical study within 1 month before recruitment; evidence of significant uncontrolled concomitant disease which in the investigator's opinion would preclude subject participation; immunologically compromised subject; pregnant and lactating women were excluded from the study.

\section{Clinical Evaluation:}

End point evaluation visits were made at baseline and at the end of $1 \mathrm{st}$, 2nd, 3rd, 4th, 5thand 6th, cycle of intervention. Assessing the comparative effect of AntiKoch's treatment (DOTs) as a single and along with Jivantyadi Ghrit was considered the primary efficacy variable and recorded at every visit. Outcome was assessed using subjective, objective parameters and global assessment of overall effect by physician and patient at each visit. And overall assessment of therapy was assessed at the end of visit.

\section{Subjective Parameters of Assessment:}

Kaphanishthivan (cough with expectoration); Jwara-sayambali (fever- evening rise); Bhar shay (weight loss); Kshudhamandya (loss of appetite); Hastapadtaldaha (burning feet and hands); Global assessment of overall effect by physician and patient. Assessment of side effects were done.

\section{Objective Parameters of Assessment:}

Pathological investigations- Hemoglobin, lymphocyte, Eosinophil, ESR, Serum bilirubin, SGPT, Blood sugar (Random) were performed at base line with every visit and at the end of the study.

Safety and Adverse Events: Safety was assessed by using standardized scale: Global assessment of overall safety as per the physician at each visit. And adverse events were also documented at each visit.

\section{Interventions:}

In Group A only AKT (DOTs) was administered according to weight immediate after meal. In Group B, Jivantyadi Ghrit with AKT (DOTs) was administered with milk immediate after meal. Group A and B patients were treated for six months with interval of 30 days visit.

Statistical Analysis: Data is analysed by using t- test to test the efficacy for quantitative data. Here results are significant if $\mathrm{p}$ - value is less than 0.05 . 


\section{OBSERVATIONS AND RESULTS}

In the present research study 54 patients were allocated for intervention. In Group A, 27 patients were enrolled, among those 12 patients were dropped out from the study. In Group B, 27 patients were enrolled, among those 14 patients were dropped out. Thus, in Group A, 15 patients, and in Group B, 13 patients were completed the study. Hence data of total 28 patients was analysed.

Figure 1
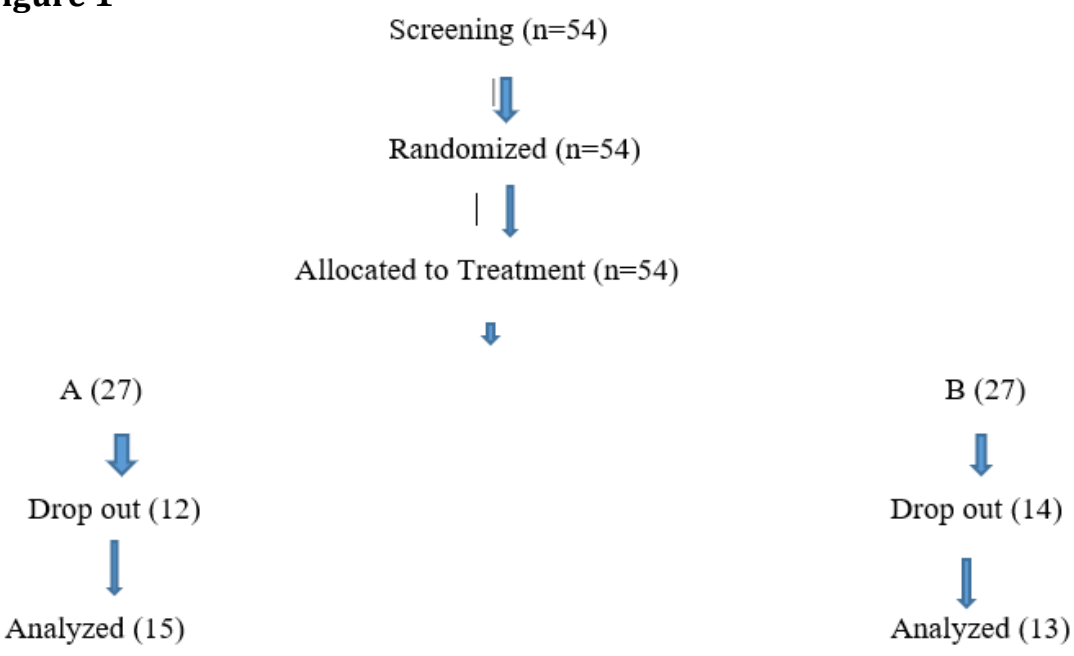

Figure1 Study Design

\section{Subjective Parameters of Assessment:}

\section{Cough with Expectoration (Kaphanishthivan)}

In experimental group, there were $21(77.77 \%)$ patients had cough with expectoration grade 1 which has reduced to $3(23.1 \%)$ whereas in control group, there were $24(88.8 \%)$ patients with cough with expectoration grade 1 which has reduced to 10 patients (66.6\%). The reduction is more in experimental group as compared to control group.

In experimental group, there were $6(22.23 \%)$ patients had cough with expectoration grade 2 which has reduced to 0 , whereas in control group, there were $2(7.4 \%)$ patients with cough with expectoration grade 2 which has reduced to 0 cases. In experimental group, there were 0 patients had cough with expectoration grade 0 which has reduced to $10(76.9 \%)$ patients, whereas in control group, 1 patient $(3.7 \%)$ had grade 0 cough with expectoration which has reduced to 5 $(33.3 \%)$ patients.

\begin{tabular}{|ccccc|}
\hline Symptoms & $\begin{array}{c}\text { Experimental } \\
\text { Group }\end{array}$ & $\begin{array}{c}\text { Control } \\
\text { Group }\end{array}$ \\
\hline $\begin{array}{c}\text { Cough with } \\
\text { expectoration }\end{array}$ & $\begin{array}{c}\text { Before } \\
\text { study }\end{array}$ & After study & $\begin{array}{c}\text { Before } \\
\text { study }\end{array}$ & After study \\
Grades & 0 & $10(76.9)$ & $1(3.7)$ & $5(33.3)$ \\
0 & $21(77.77)$ & $3(23.1)$ & $24(88.8)$ & $10(66.6)$ \\
1 & $6(22.23)$ & 0 & $2(7.4)$ & 0 \\
\hline 2 & 27 & 13 & 27 & 15 \\
\hline
\end{tabular}




\section{Loss of Appetite (Kshudhamandya)}

In experimental group, there were $22(81.4 \%)$ patients had loss of appetite grade 1 which has reduced to $1(7.6 \%)$ whereas in control group, there were 23 $(85.1 \%)$ patients had loss of appetite grade 1, which has reduced to 5 patients $(33.3 \%)$. The reduction is more in experimental group as compared to control group.

In experimental group, there were $5(18.5 \%)$ patients had loss of appetite grade 2 , which has reduced to 0 , whereas in control group, there were $3(11.1 \%)$ patients had loss of appetite grade 2 , which has reduced to 0 cases. In experimental group, there were 0 patient had loss of appetite grade 0 , which has reduced to $12(92.3 \%)$ patients, whereas in control group, $1(3.7 \%)$ patient had loss of appetite grade 0 , which has reduced to $10(66.6 \%)$ patients.

\begin{tabular}{|ccccc|}
\hline Symptoms & \multicolumn{2}{l}{ Experimental Group (B) } & \multicolumn{2}{c|}{ Control Group(A) } \\
\hline $\begin{array}{c}\text { Loss Of Appetite } \\
\text { Grades }\end{array}$ & Before Study & After Study & Before Study & After Study \\
0 & 0 & $12(92.3)$ & $1(3.7)$ & $10(66.6)$ \\
\hline 1 & $22(81.4)$ & $1(7.6)$ & $23(85.1)$ & $5(33.3)$ \\
\hline 2 & $5(18.5)$ & 0 & $3(11.1)$ & 0 \\
\hline Total & 27 & 13 & 27 & 15 \\
\hline
\end{tabular}

\section{Loss of weight (Bharkshaya)}

In experimental group, there were $4(14.8 \%)$ patients had loss of weight grade 1 , which has reduced to 0 , whereas in control group, there were $2(7.5 \%)$ patients had loss of weight grade 1 , which has reduced to $1(6.7 \%)$ patient.

In experimental group, there were 23 (85.1\%) patients had loss of weight grade 0 , which has reduced to $13(100 \%)$, whereas in control group, there were 25 $(92.5 \%)$ patients had loss of weight grade 0, which has reduced to $14(93.3 \%)$ patients.

\begin{tabular}{|ccccc|}
\hline Symptoms & \multicolumn{2}{c}{ Experimental Group (B) } & \multicolumn{2}{c|}{ Control Group (A) } \\
\hline $\begin{array}{c}\text { Loss Of Weight } \\
\text { Grades }\end{array}$ & Before Study & After Study & Before Study & After Study \\
0 & $23(85.1)$ & $13(100)$ & $25(92.5)$ & $14(93.3)$ \\
1 & $4(14.8)$ & 0 & $2(7.5)$ & $1(6.7)$ \\
Total & 27 & 13 & 27 & 15 \\
\hline
\end{tabular}

\section{Evening rise of temperature (sayambali jwara)}

In experimental group, there were $23(85.1 \%)$ patients had evening rise of temperature grade 1 , which has reduced to $1(7.7 \%)$, whereas in control group 23 $(85.1 \%)$ patients had evening rise of temperature grade 1 , which has reduced to 5 (33.33\%).

In experimental Group, there were 4 (14.9\%) patients had evening rise temperature grade 2, which has reduced to 0 cases. In control group, 4 (14.9\%) patients had evening rise temperature grade 1 , which has reduced to 0 cases. In experimental group, there were 0 patients had evening rise temperature which has 
reduced to 12 (92.3\%) patients, whereas in control Group 0 patients had evening rise temperature grade 0 , which has reduced to $10(66.67 \%)$ patients.

\begin{tabular}{|ccccc|}
\hline Symptoms & Experimental & & $\begin{array}{c}\text { Control } \\
\text { Group }\end{array}$ \\
\hline $\begin{array}{c}\text { Evening Rise of } \\
\text { Temperature } \\
\text { Grades }\end{array}$ & $\begin{array}{c}\text { Before } \\
\text { Study }\end{array}$ & After Study & $\begin{array}{c}\text { Before } \\
\text { Study }\end{array}$ & After Study \\
0 & 0 & $12(92.3)$ & & $10(66.67)$ \\
\hline 1 & $23(85.1)$ & $1(7.7)$ & $23(85.1)$ & $5(33.33)$ \\
2 & $4(14.9)$ & 0 & $4(14.9)$ & 0 \\
\hline Total & 27 & 13 & 27 & 15 \\
\hline
\end{tabular}

\section{Burning feet and hands (Hastapadtaldaha)}

In experimental Group, there were 15 (55.56\%) patients had burning feet and hands which has reduced to 1 (7.69\%) patient, whereas in control group, 16 (59.26\%) patients had burning feet and hands grade 1, which has reduced to 5 (33.33\%) patients. In experimental Group, there were 12 (44.44\%) patients had burning feet and hands grade 0 , which has reduced to $12(92.31 \%)$ patients, whereas in control Group, $11(40.74 \%)$ patients had burning feet and hands grade 0 , which has reduced to $10(66.67 \%)$ patients.

\begin{tabular}{|ccccc|}
\hline Symptoms & \multicolumn{3}{c}{ Experimental Group } & Control Group \\
\hline $\begin{array}{c}\text { Burning Feet } \\
\text { Grades }\end{array}$ & Before Study & After Study & Before Study & After Study \\
\hline 0 & $12(44.44)$ & $12(92.31)$ & $11(40.74)$ & $10(66.67)$ \\
\hline 1 & $15(55.56)$ & $1(7.69)$ & $16(59.26)$ & $5(33.33)$ \\
\hline Total & 27 & 13 & 27 & 15 \\
\hline
\end{tabular}

\section{Assessment of side Effects:}

Arthralgia Analysis shows that, number of patients having arthralgia in the experimental group has reduced from $8(44.4 \%)$ to $2(15 \%)$ as compared to control group where it has increased from $6(28.57 \%)$ to $12(80 \%)$ patients.

Jaundice In experimental group, jaundice was present in 1 patient which has reduced to 0 cases, whereas in control group jaundice was present in 4 (19.05\%) patient which has reduced to $2(13.33 \%)$ cases.

Nausea In experimental group, nausea was present in 4 (22.23\%) patient which has reduced to 0 patient. In control group, nausea, nausea was present in 15 $(71.43 \%)$ patient which has reduced to $9(60 \%)$ patients.

Rashes In experimental group, rashes were present in $4(22.22 \%)$ patient which has reduced to $1(7.69 \%)$ patient. In control group, rashes were present in 10 $(47.62 \%)$ patients before study which has reduced to $1(7.69 \%)$ patient. 
Table 2

\begin{tabular}{|c|c|c|c|c|}
\hline \multicolumn{5}{|c|}{$\begin{array}{l}\text { Table } 2 \text { Comparison of Effectiveness of Treatment Between } 2 \text { Groups For Subjective } \\
\text { Parameters }\end{array}$} \\
\hline \multirow[t]{2}{*}{ Side effects } & \multicolumn{2}{|c|}{ Experimental group (B) N (\%) } & \multicolumn{2}{|c|}{ Control group (A) N (\%) } \\
\hline & Before study & After study & Before study & After study \\
\hline \multicolumn{5}{|l|}{ Arthralgia } \\
\hline Present & $8(44.44)$ & $2(15.38)$ & $6(28.57)$ & $12(80)$ \\
\hline Absent & $10(55.56)$ & $11(84.6)$ & $15(71.43)$ & $3(20)$ \\
\hline Total & 18 & 13 & 21 & 15 \\
\hline \multicolumn{5}{|l|}{ Jaundice } \\
\hline Present & $1(5.56)$ & 0 & $4(19.05)$ & $2(13.33)$ \\
\hline Absent & $17(94.44)$ & $13(100)$ & $17(80.95)$ & $13(86.67)$ \\
\hline Total & 18 & 13 & 21 & 15 \\
\hline \multicolumn{5}{|l|}{ Nausea } \\
\hline Present & $4(22.23)$ & 0 & $15(71.43)$ & $9(60)$ \\
\hline Absent & $14(77.77)$ & $13(100)$ & $6(23.57)$ & $6(40)$ \\
\hline Total & 18 & 13 & 21 & 15 \\
\hline \multicolumn{5}{|l|}{ Rashes } \\
\hline Present & $4(22.22)$ & $1(7.69)$ & $10(47.62)$ & $1(7.69)$ \\
\hline Absent & $14(77.78)$ & $12(92.31)$ & $11(52.38)$ & $12(92.31)$ \\
\hline Total & 18 & 13 & 21 & 13 \\
\hline
\end{tabular}

\section{Objective Parameters of Assessment:}

Hemoglobin level. Statistical analysis shows that, p-value for experimental group is greater than 0.05 and for control group, p-value less than 0.05 , hence we conclude that on mean hemoglobin level observed that in experimental group, it's not significant but in control group it is significant.

WBC. Statistical analysis shows that, $\mathrm{p}$ - value for both the groups are less than 0.05 , hence we conclude that effect on mean total leukocyte count (WBC) observed was significant in both the groups.

Lymphocyte Count. Statistical analysis shows that, p- value for experimental group is less than 0.05 , hence it is significant, whereas p- value for control group is greater than 0.05 , hence it is not significant.

Granulocyte. Statistical analysis shows that, p-value for both the groups is less than 0.05 , hence we conclude that, effect on mean granulocyte count observed was significant in both the groups.

ESR. Statistical analysis shows that p-values for two groups are less than 0.05 , hence we conclude that, effect on mean ESR score observed was significant in both the groups.

Blood Sugar level. Statistical analysis shows that, p- values for two groups are greater than 0.05 , hence we conclude that effect on blood sugar level was not significant in both the groups.

Serum Bilirubin level. Statistical analysis shows that, $\mathrm{p}$ - values for both the groups are greater than 0.05 , hence we conclude that effect on serum bilirubin level was not significant in both the groups. 
Table 3

\begin{tabular}{|c|c|c|c|c|c|c|}
\hline \multirow{3}{*}{$\begin{array}{c}\text { Pathological } \\
\text { Parameters }\end{array}$} & \multicolumn{3}{|c|}{ Experimental Group (Group B) } & \multicolumn{3}{|c|}{ Control Group (Group A) } \\
\hline & $($ Mean \pm SD $)$ & & & $($ Mean \pm SD $)$ & & \\
\hline & $\begin{array}{l}\text { Before } \\
\text { study }\end{array}$ & After study & & $\begin{array}{l}\text { Before } \\
\text { study }\end{array}$ & After study & \\
\hline Hemoglobin & $9.39 \pm 1.95$ & $10.24 \pm 3.69$ & $P=0.87$ & $9.89 \pm 2.02$ & $11.66 \pm 1.45$ & $\mathrm{P}=0.003$ \\
\hline WBC & $8.73 \pm 3.55$ & $5.55 \pm 1.98$ & $\mathrm{P}=0.006$ & $9.61 \pm 4.16$ & $4.99 \pm 1.29$ & $\mathrm{P}=0$ \\
\hline Lymphocyte & $17.68 \pm 12.72$ & $29.62 \pm 13.27$ & $P=0.01$ & $18.73 \pm 7.64$ & $35.30 \pm 8.94$ & $P=0.4$ \\
\hline Granulocyte & $79.02 \pm 6.74$ & $63.19 \pm 13.73$ & $P=0.0002$ & $74.66 \pm 9.01$ & $56.24 \pm 10.54$ & $\mathrm{P}=0$ \\
\hline ESR & $79.48 \pm 26.40$ & $25.93 \pm 42.46$ & $\mathrm{P}=0.0001$ & $80.37 \pm 31.23$ & $25.93 \pm 26.44$ & $\mathrm{P}=0$ \\
\hline $\begin{array}{c}\text { Random Blood } \\
\text { Sugar }\end{array}$ & $97.84 \pm 19.33$ & $97.72 \pm 23.06$ & $\mathrm{P}=0.98$ & $99.23 \pm 28.71$ & $86.74 \pm 21.83$ & $P=0.22$ \\
\hline Serum Bilirubin & $0.76 \pm 0.22$ & $0.85 \pm 0.27$ & $P=0.59$ & $0.85 \pm 0.17$ & $0.80 \pm 0.15$ & $\mathrm{P}=0.84$ \\
\hline SGPT & $24 \pm 9.95$ & $23.84 \pm 8.6$ & $\mathrm{P}=0.44$ & $22.09 \pm 10.51$ & $19.67 \pm 8.17$ & $P=0.20$ \\
\hline Overall score & $1.39 \pm 0.50$ & $1.31 \pm 0.48$ & $P=0.61$ & $1.86 \pm 0.35$ & $1.53 \pm 0.516$ & $P=0.06$ \\
\hline General score & $4.11 \pm 0.45$ & $4.62 \pm 0.50$ & $\mathrm{P}=0.003$ & $3.86 \pm 0.35$ & $4.20 \pm 0.41$ & $P=0.02$ \\
\hline
\end{tabular}

Note: $t$ test has been applied. $95 \%$ Confidence

\section{DISCUSSION}

\section{Discussion on Rajayakshma:}

Rajayakshma is described in an oldest literature Rig-Veda. Since that time human being suffering from the disease. It is the disease of pranavaha strotas. Hriday and dashwahi dhamanyas are the moolsthan of pranavaha strotas. Rasa is flowing through the dhamanis and vata residing in the hriday. Over exertion (exceeding one's own capacity), suppression of natural urges, depletion of tissue element (dhatu shay), and vishmashan (irregular dieting) are the causative factors for Rajayakshma. Shastri (n.d.) Due to dominance of kaph Pradhan dosha, rasavaha strotas gets obstructed which leads to dhatu Shaya. Also due to atimaithun (masturbation) shukradhatu kshay occurs which further leads to purvapurvadhatukshay gradually. This leads to shosh in the individual suffering. All these factors have to be taken in consideration in samprapti (pathogenesis) and chikitsa (treatment) of Rajayakshma.

As per Ayurveda texts, Yakshma is a disease of madhyam rogmarga and affects phupphus (lungs). As all the doshas are responsible for the samprapti, the concept of chikitsa based for the strengthening of doshas as well as dhatus. In Ayurveda texts, Acharya indicate particular line of treatment of Rajayakshma which are as follows -

1) Shadang Ajaras (Goat's bone soup)

2) Avaleha - Khajur, Duralabha, Pippali, Sunthi etc.

3) Ghrut - Duralabhadi and Jivantyadi Ghrut. Kushwaha (2019)

\section{Discussion on Jivantyadi Ghrut:}

In the present research study, Jivantyadi Ghrit was used as an adjunct therapy with DOTs (AKT). As it is containing 14 herbs, having properties such as Agni Deepan (appetizer), Aampachan (Digestive), strotovishodhan (removal of waste metabolites) and rasayanguna may leads to samprapti bhang (Breaking of 
pathogenesis) and significant action. Actions of contents of Jivantyadi Ghrut may be categorized as below-

1) Jwarhar (Anti-pyretic) - Yashthimadhu, Mrudvika, Nilkamal, Bhumyamlaki, Trayman, Kutaj. Sharma et al. (2005)

2) Chhedan (Expectorant) - Drugs acting on respiratory system - Jivanti, Yashthimadhu, Mrudvika, Shati, Pushkarmool, Kantakari, Pimpli, Dhamasa. Sharma et al. (2005)

3) Deepan (Appetizers), Hepatoprotective - Trayman, Bhumyamlaki, Jivanti. Sharma et al. (2005)

4) Bruhan, Balya, Dhatuvardhak (Ras Ayan) - Yashthimadhu, Mrudvika, Gokshur, Bala, Nilkamal, Jivanti, Pimpli Lavekar et al. (2008)

The chemical components of pushkarmool is inulin which is having antimicrobial action. Jivanti had shown anti stress, antioxidant, and immune stimulant activity. Diosgenin is the chemical components of kantkari having antiinflammatory action. Tray Amana containing gentiopicrin is gastric stimulant which modulates the appetite. Flavonoid having anti-inflammatory, anti-microbial activity which is chemical components of Bhuiamla. Saponin is the chemical components of dhamasa having anti-inflammatory activity. Saponin having immune stimulating activity which reduces the future risk of recurrence of Rajyakshma.

\section{Discussion on clinical Study:}

The study was an active, controlled, randomized study, designed to evaluate the efficacy of Jivantyadi Ghrut as add- on treatment in PTB treating with AKT (DOTs) regimen after 180 days of treatment. For the current research work, 54 clinically diagnosed patients of PTB were selected and randomly divided into following two groups of twenty-seven patients each. In Group A, twenty-seven patients were enrolled, among those twelve patients were dropped out from the study. In Group B, twenty-seven patients were enrolled, among those fourteen patients were dropped out. Thus, in Group A, fifteen patients and in Group B, 13 patients were completed the study. Hence data of total 28 patients are analysed.

\section{Group A}

- DOTs (AKT) - According to weight

- Time of administration - Aadrapaani (Immediate after meal)

\section{Group B}

- Jivantyadi Ghrit with DOTs (AKT)

- Anupan - Milk

- Time of administration - Aadrapaani (Immediate after meal)

Group A and Group B patients were treated for 6 months

\section{Discussion on Demographical Data}

Age -Patients belonging to age between 18 to 60 years were included in the present study. Among total 54 patients, $34.48 \%$ patients belong to the age group of 51-60 years, followed by $25.92 \%$ patients belongs to the age group of 21-30 years. $20.37 \%$ patients were belonging to the age group of $10-20$ years and $31-40$ years and $41-50$ years age group $11.11 \%$, and $11.11 \%$ patients belongs to this age group, 
respectively. This data indicates that, the disease is common in 51-60 years of age, which is an old age group.

Gender -In all two groups, incidence of Rajyakshma (PTB) in males was maximum. Among total 54 patients, male patients were 42 and female patients were 12 , i.e., $77.77 \%$ and $22.22 \%$ patients, respectively. This indicates that Rajyakshma seen more in males than females. Even the data also support the prevalence of Rajyakshma is more in men in India (TB case notification 2019 India, Male - 59\% and Women 34\%) WHO Global Report (2020)

\section{Discussion on Subjective and Objective Parameters of Assessment}

1) Cough with expectoration - One of the important and cardinal symptoms of Rajyakshma. There is significant reduction in cough with expectoration in experimental group as compared to control group. By the administration of JivantyadiGhrut along with DOTs (AKT), drugs having chhedan (expectorant) action reduces the severity of the cough with expectoration and relieves the strotorodh.

2) Loss Of Appetite - Trayman, Bhumya Malaki and Jivanti having deepen and hepatoprotective action which stimulate the appetite. There is significant improvement in experimental group as compared to control group.

3) Loss Of Weight-Gradual weight loss is another symptom of Rajyakshma which occurs due to dhatu shay. Immuno-modulator, gastric stimulant and rasayan drugs of Jivantyadi Ghrut having significant role in improvement in loss of weight.

4) Evening Rise of Temperature -Yashtimadhu, Bhumya Malaki, Nilkamal having Jwarhar properties which help to decline the temperature. There is significant improvement in reducing the evening rise of temperature as compared to control group.

5) Burning Feet and Hands - As loss of appetite lead to the lack of nutrition of dhatu. This phenomenon leads to the burning feet and hands. Saponin and flavonoids having anti- inflammatory action which responsible for strotovishodhan (removal of waste metabolites) which is having significant role in improving the burning feet and hands as compared to control group.

6) Arthralgia, Jaundice, Nausea -These are the adverse effect of antitubercular drugs. There is significant reduction of score in Group B than A. This data suggests that JivantyadiGhrut along with DOTs (AKT) having immune modulator, rasayan effect on the patient which further reduces the recurrence of PTB.

\section{Discussion on Pathological Parameters}

1) Lymphocyte Count - There was significant reduction of score in Group B, as compared to Group A. Jivantyadi Ghrut having anti-microbial activity.

2) WBC, Granulocyte, ESR -Due to microbial invasion these count increases. There is significant reduction in both the groups.

3) Hemoglobin - There is significant reduction of score in control group as compared to experimental group.

4) Blood Sugar (Random), Serum Bilirubin, SGPT -There was not significant reduction of score in both the groups of these pathological parameters. All the patients of two groups tolerated interventions very well and not a single patient complained about side or toxic effects of drugs used in the present 
trial. Need and time to work on large number of sample size to prove the immunomodulator, rasayan, anti-microbial effect of JivantyadiGhrut along with DOTs (AKT) to reduce the regimen and recurrence of pulmonary tuberculosis which will provide more concrete solution in future for the human being to get rid of the infectious disease.

\section{CONCLUSION}

- Cough with expectoration, loss of appetite, loss of weight, evening rise of temperature and burning feet and hands are the major complaints of Rajyakshma was significantly reduced in group B i.e., JivantyadiGhrut with AKT (DOTs) treated patients.

- Significant more reduction in arthralgia, jaundice and nausea which are side effects of anti-tubercular drugs which found in patients treated with Jivantyadi Ghrut with AKT (DOTs) treated patients.

- As far as pathological parameters are concerned, there was significant reduction of score in lymphocyte count in Group B patients

- There was significant reduction of ESR, Granulocyte and WBC count in both the groups whereas concerning with hemoglobin, there was significant reduction of score in control groups.

- Jivantyadi Ghrut with DOTs (AKT) was found effective in the management of Rajayakshma (Tuberculosis). Need more research work for best outcome.

\section{ACKNOWLEDGEMENTS}

I thank Hon. Vice Chancellor, Registrar, Deputy Registrar, UDC and URD department of Maharashtra University of Health Sciences, Nashik (Maharashtra) for sanctioning grant and administrative support.

\section{REFERENCES}

Haris, V. Kushwaha, C. S. (2012). The Caraka Samhita Second Part, 234.

Kasper, D. L., Braunwald, E.,Fauci, A. S., Hauser, S. L., Longo, D. L. Jameson, J. L. (2005). Harrison's Manual of Medicine (16th ed.). McGraw Hill Professional. Kushwaha, H. C. S. (2019). Caraka Samhita, Varanasi : Chaukhambha Orientalia, 232. Kumar, V., Abbas, A. K., Fausto, N., Mitchell, R. (2007). Robbins Basic Pathology (8th ed.), Elsevier Health Sciences.

Lavekar, G.S. Padhi, M.M. Joseph, G.V.R. Selvarajan, S. Yelne, M.B. Mangal, A.K. Raman, K. G. Sharma, P.C. and Dennis, P.C. (2008). Database on Medicinal Plants Used in Ayurveda and Siddha. Central Council for Research in Ayurveda and Siddha.5,43-47.

Sharma. R. K. (2007). Agnivesha, Charaka, Dridhabala, Reprint CharakSamhita, Chikitsasthana, Rajyakshmachikitsa adhyaya, 279.

Shastri, S. Upadhyay, Y. Tika, M. (2008). Madhava Nidana (Purvardha). Varanasi : Chaukhambha Prakashan.

Shastri, K. A. (2005). Susruta Samhita. Varanasi : Chaukhambha Sanskrit Sansthan, 241.

Shastri, S. S. (n.d.). Madhav Nidan, Chaukhambha Sanskrit Sansthan, 29 th edition, Varanasi, 246.

Sharma, P. C. Yelne, M. B. Denris, M. B. (2005). Database on Medicinal Plants used in Ayurveda and siddha, 2, 270-273, 347-349. 
Sharma, P. C. Yelne, M. B. Denris, T. J. (2005). Database on Medicinal Plants Used in Ayurveda and siddha, 3, p229-232, 472-475, 512-515, 561-564.

Sharma, P. C. Yelne, M. B. Denris, T. J. (2005). Database on Medicinal Plants Used in Ayurveda and siddha, 4, p 251-256, 269-273, 505-508.

Tripathi, K. D. (2018). Essentials of Medical Pharmacology (6th ed.). New Delhi : Jaypee Brothers Medical Publishers.

WHO Global Report (2020). 